\title{
Promoting student interest in science: The impact of a science theatre project
}

\author{
Lydia Schulze Heuling
}

Department of Sport, Food and Natural Sciences, Western Norway University of Applied Science, Norway

Researchers have often noted the potential of the performing arts to support STEM education - especially in heterogeneous classrooms. This article reports on the implementation of a science theatre project in a secondary school class located in a disadvantaged area of Hamburg (Germany). In the accompanying research study, effects on students' interest in STEM and artistic expression were surveyed. Data analysis using $t$-tests shows that the artistic work significantly increased students' interest in physics and chemistry, and specifically in the process of galvanization, the project's focus topic. The analysis also revealed a growth in students' knowledge of cultural practices, self-confidence, joy in individual artistic expression, and classroom spirit during the course of the project.

Keywords: STEAM education, science theatre, art-informed education, out-ofschool learning, cultural education
ARTICLE DETAILS

LUMAT Special Issue

Vol 9 No 2 (2021), 63-81

Received 22 January 2021

Accepted 23 February 2021

Published 18 March 2021

Pages: 19

References: 58

Correspondence: Ishe@hvl.no

https://doi.org/10.31129/ LUMAT.9.2.1489

\section{Introduction}

In today's schools, globalization is progressively increasing diversity as students from a broad spectrum of social, ethnical, and personal backgrounds bring a wide range of cultural habits and practices, expectations and beliefs, interests and languages to the classroom. Yet standard classroom teaching in Western industrialized societies supports and reproduces a unitary and linear concept of science, one that is communicated and supported via teacher-centered and recipe-like instructional techniques. This way, "conceptual practices of culturally others" (van Eijck \& Roth, 2011) are excluded from Western science and science education. At the same time, solid science and technology skills are needed if students are to become informed and responsible members of our knowledge and information society (Kolstø, 2001). One potentially very effective way to promote culturally diverse and inclusive science and technology education is to connect it to creativity and the arts (Reif \& Grant, 2010; Madirosian, 2003). In this article, I describe and analyze how a performing-arts informed teaching project about galvanization affected classroom learning with $13^{-}$to 16-year-old girls and boys at a German district school. The study focuses on the question, if the science theatre project helped to increase students' interest in physics, chemistry, galvanization, and artistic practice. 


\section{From STEM to STEAM}

About fifty years ago, at the opening of the San Francisco Science Centre, its founder Frank Oppenheimer stated that science, art, and human perception are entwined (1972). In this vein, physicist Kent Eschenberg (2006) notes that outstanding research in the fields of natural sciences is related to the "ability to imagine new realities" and to abilities that "are traditionally thought to be non-scientific skills". And Guy Boy, a physicist at Kennedy Space Center, discusses the need to integrate the arts into STEM (science, technology, engineering, and mathematics), creating STEAM, to account for the complexity of phenomena, knowledge, and knowledge creation. He points out that, particularly in education, transdisciplinary connections between STEAM areas are required to account for the intricate lifeworlds of young people (Boy, 2013). During the past decades, the notion for STEAM has increased (Perignat \& KatzBuonincontro, 2019). The "Arts at CERN" project is another strong indicator that STEAM is no longer a marginal perspective:

[Arts at CERN seeks to] pioneer new ways of bringing together artists and scientists [to] lead the conversation about art and science [...]. Positioning artists and scientists together within the larger scientific context, our programmes foster new approaches to research, experimentation, and artistic production. Furthermore, we want to question how art and culture can form novel visions of a highly specialized environment and what common grounds can be shared between art and science. (CERN, 2020)

\subsection{STEAM in education}

While STEM researchers are more and more informed or sensitized about STEAM, predominant paradigms and practices of teaching STEM in schools present the disciplines as static, coherent, and linear, projecting it as a self-sustaining, selfreproducing cognitive process (Schulze Heuling, 2017). STEAM can provide a responsive pathway for education towards 'whole STEM learning' (Allchin \& Zemplen, 2020) in which students experience themselves as 'science makers,' thus enabling them to engage with the complexity of STEM undertakings instead of discouraging potentially interested teenagers from developing an interest in STEM. Furthermore, with teaching towards STEAM rather than STEM, educators can provide an education to their students that fosters diverse and culturally responsive classrooms by enabling the co-creation of contextual knowledge such as aesthetical, emotional, biographical, embodied and practical knowledge in relation to STEM (Gedžune \& Gedžune, 2011; Reif \& Grant, 2010). Typical ways towards integrating the arts in STEM education are 
art-informed and art-based approaches (Khine \& Areepattamannil, 2019; Marshall, 2014): Art-informed teaching refers to approaches which can be characterized as using the arts and art-related creative processes and products as vehicles for conventional subject education. In contrast, art-based education in STEM, which can also be referred to as STEAM education, aims to teach towards STEAM, acknowledging the arts and artistic processes as an epistemic praxis of equal value.

A growing body of research into art-informed and STEAM education confirm positive educational effects. Art-based or art-informed learning and instruction in STEM-subjects enhances students' intrinsic motivation (Reimer, 1970; Fiske, 1999; Eisner, 2002; Irving, 2015), lesson commitment (Stronge, 2002), social learning (Mardirosian \& Fox, 2003) and cognitive development (Schellenberg, 2003; Miendlarzewska \& Trost, 2013). Other studies found that students react to art-based education with increased learning commitment (Ritter, 1999), stamina (Stronge, 2002), and an increased willingness to take risks with respect to knowledge discovery (Jensen, 2001). Positive effects were found for higher-order thinking (Burton, Horowitz, \& Abeles, 1999), critical thinking and reflection (Snyder, 2017), conceptual thinking (Efland, 2002), as well as interdisciplinary and interlaced thinking (Psilos, 2002). Furthermore, art-based instruction is found to be a mediator variable for learning, one that shows a positive influence on students' ability to learn independently (Fiske, 1999). Several studies provide evidence that dance and performance art support students' inquiry learning and communication skills in verbal and non-verbal ways and foster an integrated learning process in STEMsubjects (Burg \& Lüttringhaus, 2005; Le Maréchal, Bertin, \& Hallet-Eghayan, 2009; Gollin, 2016; Najami, Hugerat, Kjalil, \& Hofstein, 2019).

Furthermore, art-based and art-informed education increases teachers' (Oreck, 2014; Garvis \& Pendergast, 2010) and especially STEM teachers' (Macintyre, Buck, \& Beckenbauer, 2007; Tracey, 2009) self-efficacy. Particularly prospective STEM teachers benefit from integrating the arts in non-arts subjects because it fosters the interconnection of knowledge gained from different subject areas (Amabile, 1983; Weisberg, 1999; Veen, 2015; Irving, 2015). Evaluation of the North Carolina school program "the arts and education reform" showed that art-based techniques provide teachers effective tools that help them to teach adaptively and support students individually (North Carolina A+, 2020). Burton, Horowitz, and Abeles support these findings and show that art-based teacher trainings increase instructors' willingness to participate in further trainings (Burton et al., 1999). 
Predominant art forms in conjunction with science and mathematics education are the performing arts (Heering \& Schulze Heuling, 2020; Williams, 2011; Stolberg, 2006). As Stolberg suggests in his review, one reason the performing arts in science and mathematics education are preferred over other art forms is that they adaptively allow for collective work in larger groups. However, all art forms allow the artistic modelling or inquiry processes taking place in the classroom to be dynamic and performative.

This might be one reason why it is now becoming increasingly common also for university lecturers to teach STEM alongside performing arts. Lucy Irving and Carl Senior, for example, have developed an entire YouTube tutorial in which they present choreographies to explain basic statistics (Irving, 2015). Others go beyond the representational state of artistic expression entwining aesthetical, emotional, embodied and practical knowledge. For example, Schultz and Brackbill (2009) successfully improved medical students' abilities to interpret electrocardiograms by infusing their lessons with rhythmic dance movements. Karen William's (2011) introductory courses to lab techniques in the science laboratory are informed by choreography and motion analysis. Characteristic for her approach is the understanding of the hidden, non-verbalized somatic knowledge of lab routines as choreographies themselves. Finally, some studies show that the arts are furthermore extremely promising for student assessment (Katz, 2016; Veen, 2012; Knowles \& Cole, 2008; Macintyre et al., 2007; Soep, 2005).

\section{Models and approaches for integrating the arts in STEM education}

There are several models for integrating the arts in (non-arts) education (Fogg \& Smith, 2001; Annenberg, 2003; Leavy, 2015) of which two should be introduced here. The model developed by the Lincoln Center is called "Aesthetic Education, Inquiry, and the Imagination" (Greene, 2001; Holzer, 2005). One major characteristic of the model is that it has been derived from educational practices that focus on aesthetic learning. Its core qualities are comprehended in nine "capacities": noticing deeply, embodying, questioning, identifying patterns, making connections, exhibiting empathy, living with ambiguity, creating meaning, taking action, reflecting and assessing. Physicists have identified five of these capacities (noticing deeply, embodying, questioning, identifying patterns, and making connections) as directly relevant to their research and educational practice (Weisskopf, 1976; Veen, 2012; Boy, 
2013). The Lincoln Center is currently developing "curricular frameworks in aesthetic education" based on the nine capacities. The other model I would like to mention is the "artful learning" model of the Bernstein Center and is offered as advanced training that targets active teachers. This model groups teaching strategies, learning techniques, and suggestions for educational practice around a four-level, processoriented model-the Bernstein process of "experience, inquiry, creativity, and reflection" (Bernstein, 2003).

\section{Science Theatre}

Deliberately integrating the arts and aesthetic perception into education promotes awareness that science is culturally dependent and a conceptual and social practice. This, in turn, can help students embrace science and science-related topics as something related to their own experience. Characteristic for the intersection of science and art is the willingness to engage in a learning journey and commit to experiences that can change the way we think by means of deep observations in the world, systematic connections, interpretations, sharing and thinking. Science theatre is an amalgam, a "patchwork genre," that combines artistic research, dramaturgical and science epistemology, and content from artistic and science domains (Chemi, 2017).

As a practice, it makes use of (post-) dramatic approaches, drama pedagogical tools, and various forms of media to create and disseminate knowledge. In this sense, it is much more than merely staging a play that somehow relates to science; rather, it is a process that involves scientific and artistic practices that might or might not lead to a public demonstration. Science Theatre is a process that involves perspectives from both, art and science, and engages them in a trans-disciplinary exchange. Science theatre performances are expressions of such dialogues, of a transdisciplinary discourse in which students explore and negotiate issues related to both domains, learning about epistemologies, content matter, dramaturgical techniques, history, and philosophy as well as social, emotional, and moral aspects (Orthofer, 2013). 


\section{The project}

The project was initiated by the science teacher of the participating class. During a teacher training led by the German "Kulturagenten" (cultural agents) programme, an initiative set up to foster cultural education in schools, the teacher stated a strong need for alternative educational approaches towards science in order to reach the many atrisk students in his classes. Upon this statement, a representative of the Kulturagenten programme intensified the contact with the teacher and the school, which lies in a social focal point of Hamburg. A meeting with potential project partners was set up and finally, the Kulturagenten programme decided to fund the entire project.

The content focus of the project was on the phenomenon of galvanization and the related science disciplines physics and chemistry. Galvanization is based on the principle of electrolysis. Nowadays, galvanization is used as a technical term describing processes of surface refinement. Typically, a thin layer of a conductive metal is applied to a workpiece to protect it against corrosion. Because some of the coatings look very shiny compared to the workpiece material, it can be easily associated with something that is glamorous on the outside but might not be so glamorous on the inside. Therefore, the students gave the project the name "Not All That Glitters is Gold."

\subsection{Project preparation and overall structure}

The project was led by two artists, one artist-scientist, and the two classroom teachers of which one was the initiating science teacher. All five were involved for the duration of the project, which extended over three months. The project design was primarily determined by structural conditions of the school and pedagogical desiderata.

It furthermore aimed to provide students with artistic, cultural, and subject learning experiences and, at the pedagogical level, to give them an artistic and cultural learning process that sprang from the combined, cooperative efforts of artists, scientist and teachers. Another aim was to unite an art-based learning process with STEM-subject learning. In the project, the students negotiated scientific knowledge creation and representation as well as industrial labour and workshops in artistic ways and during classroom sessions. Moreover, it was a curricular demand that the project also addressed issues of early-career guidance which it did on behalf of the job profile of a galvanizer. 
At a first meeting, the overall time-structure of the project (see Figure 1) and the conditions of the school and the availability of the theatre space for rehearsals and working schedules were negotiated. It was set that the project should begin with a kick-off workshop (Phase 1), followed by a visit to a galvanization factory (Phase 2), a performance-art workshop (Phase 3) and an intense working week in the theatre (Phase 4) where, at the end of the week, the performance would be staged publicly. Between the kick-off workshop and the performance-art workshop, the students worked with their teachers on the theoretical fundamentals of galvanization and around the visit to the galvanization workshop (preparation for visit and reflection).

On a subsequent meeting among the three external experts, all agreed on an overall artistic-pedagogical approach and sketched the content for each of the project phases. For example, during the kick-off workshop, as a means of introducing students to scenic work with movement and speech and to STEAM, students should be made familiar with the principles of "Show and Tell" (Jackson, 2005). Show and tell combines elements of lecture and theatre, bringing together the acts of saying and showing in the context of a scenic set. Show and tell allows the participant to experience and reflect on the performative dimensions of scientific knowledge production. The aim was to increase students' sensation that STEAM offers them a pathway to experience themselves as science and technology learners or even as science and technology makers.

Further objectives of the kick-off workshop were to encourage students to apply artistic freedom and to freely associate their own impressions and ideas to scientific content and to build up their anticipation for the project. Because public presentations were scheduled to take place right at the end of the intense working week (Phase 4), it was also important to collect artistic material during Phases 1-3, such that the final intense working week could build on the three prior phases. For this reason, already during the kick-off workshop, the class was divided into smaller groups. Each of the three groups found a thematic focus which they would further explore during the course. The three groups worked on (1) working life and professions, (2) transforming phenomena of galvanization into motion, and (3) shiny but fake. 


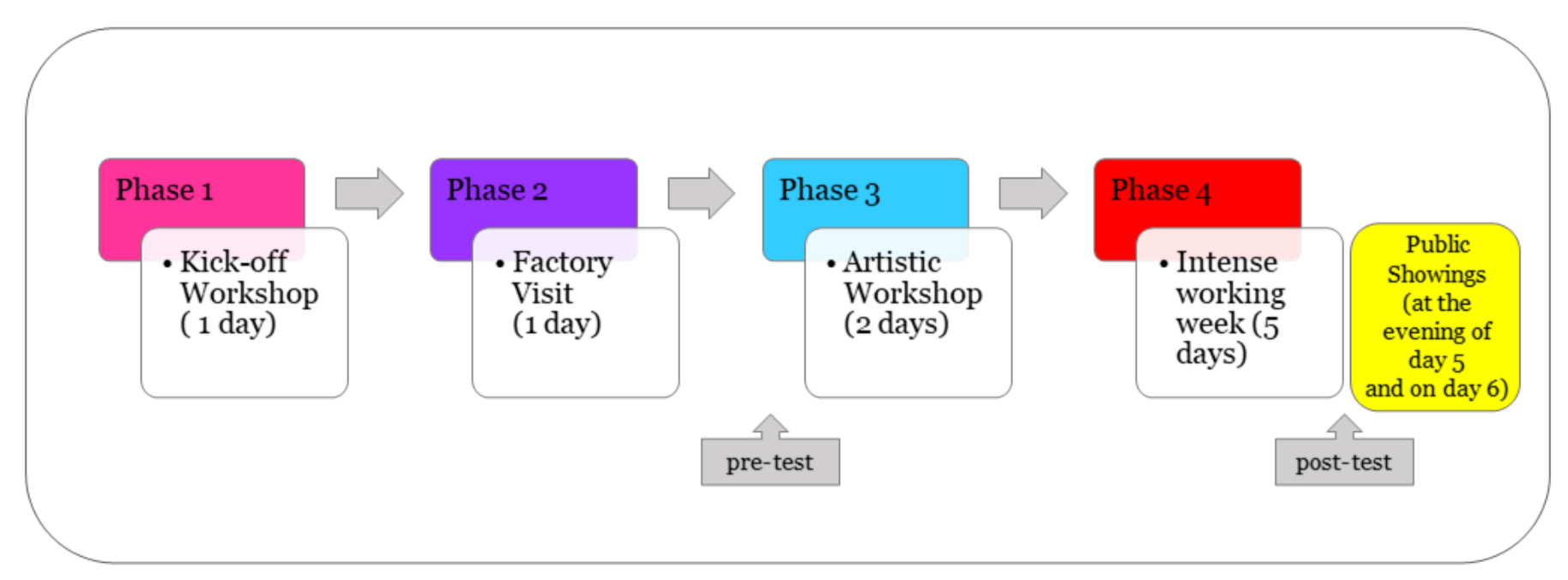

Figure 1. Timeline of the project.

\subsection{From kick-off to performing in public}

Since doing and experiencing factory work and science were important issues within the scope of this project, we wanted the students and ourselves to experience in real life what happens in a galvanization factory. To this end, after the kick-off and before the two-day artistic workshop, all project participants attended a factory tour to the Böge factory in Hamburg-Bergedorf. During the tour, students technically and sensually experienced the process of galvanization. They heard the sound of clinging metal, smelled the acidic air, and saw the physical labour of the metalworkers. The students also talked to the company owner and asked a lot of questions. Subject knowledge on galvanization was prepared in school.

One week after the field trip, the students, the three external experts, and the teachers met for the workshop on theatre practice, which took place in the Forschungstheater in Hamburg (research theatre). After a warmup, the students intensified their work with show and tell, followed by a break and then a lecture performance on galvanization given by the artists. The lecture performance was designed highly interactive. Charge transport through ionization and electrolysis, as well as sensory and social aspects of working in a galvanization factory were performed. In this way, the students were further familiarized with what it can look like to approach a techno-scientific subject from a STEAM perspective.

Finally, the students were asked to write down their ideas, wishes or unanswered questions. This list contained important information for us, the external experts, and was used as a starting point to design the intense working week (Phase 4). Analysis of the list revealed that the launch had inspired and motivated the young people, who 
offered suggestions regarding which artistic and thematic issues they would like to intensify during the project week. During the interval between this workshop and the project week itself, which would take place a couple of weeks later, students attended regular school lessons.

Phase 3 of the project, the main project week, began with an extensive warmup and performance-pedagogical ensemble work. The smaller groups worked progressively on their scenes, which were given the working titles' Transport,' 'Gangster,' and 'Fashion Show' (see Info Box). In addition, the entire class had developed the idea to negotiate their impressions of the factory visit and what they had learned about the profession of a galvanizer in the form of fictional interviews with the company leader. These interviews were partially based on students' notes made during and after the tour.

INFO BOX

\section{'Transportation'-scene}

Three bank robbers steal the gold reserve of a large bank. After a turbulent journey they successfully deliver the stolen gold to their gold-addicted boss in his all-gold headquarters. Because the boss himself is the only non-gold-plated object in the office, the gangsters decide to galvanizing him with the stolen gold.

'Gangster'-scene

Starting point of this scene was to think galvanisation the other way round. The idea is to coat a surface not to make it look shiny and precious but to make it look ordinary. In this scene the treasure of a museum robbery was delivered to a galvaniser who is asked to cover the treasure with chocolate for camouflage. Of course, this camouflage bares some surprising trouble...

\section{'Fashion-Show'-scene}

A galvanising process usually is used to refine surfaces. This scene is composed of students' associations that were born out of critical reflections with the word 'surface'. In a world of glamour and glitter a young woman refuses to wear make-up, high heels, and extra-large earrings. What are the consequences for her - and for the beauties on the catwalk? 
Since the physical phenomena of a galvanizing process should also be part of an artistic and creative learning process, the whole class developed short scenes representing what they had learned about the physical and chemical fundamentals. The first scene was a choreographic miniature inspired by classical visual models of atoms and molecules. The second choreographic miniature was a danced model of the formation of molecular bonds. The third choreographic scene was based on charge transport model of electrons and ions. The science teacher of the class used the artistic process and artistic miniatures for his classroom sessions at school to reflect on aspects and limitations of scientific models.

At the end of the project week a collective performative collage out of the different artistic material was created. There was also the possibility - particularly for those students who were interested - to participate in light and stage design and other stage management duties.

\section{Accompanying survey}

Engagement with students, work on the project, and a tight timeline meant that the pedagogues had very limited time for an in-depth project evaluation. The pragmatic choice was to monitor selected aims of the project in an accompanying pre-post questionnaire survey. The focus of this study was to find evidence if the project had an impact on students' attitudes towards the subjects of physics, chemistry, galvanization, and their appreciation of artistic practices.

\subsection{Methods and sample}

All participating students were in the eighth grade and in the same class at the lower secondary level of a German Stadtteilschule (district school). The sample was not randomized and there was no control group. All data were assessed with a questionnaire (pen and paper). There were 25 participants in each, the pre- and posttest sample. The first measurement was taken at the beginning of the first meeting in the theatre (Phase 3). Post measurement was six weeks later, at the end of Phase 4, before staging the performance to the public. All questions were to be answered on a seven-point Likert scale ( 1 = "not agree" to 7 = "fully agree").

Since this study makes the claim that combining performing arts with STEM education is particularly suitable for working with heterogeneous classrooms, the demographic and social composition as well as the distribution of personality traits of 
the present sample were surveyed. Let us first look into demographic and social characteristics: Students' intercultural background was assessed asking if another language besides German was spoken at home. This was positive for $92 \%$ of the students. A variety of free time and cultural activities was also assessed, showing that more than half of the class engages in group sports and almost a third of the class plays a music instrument. To be precise: About $23 \%$ of the students reported engaging in individual sports, $58 \%$ in team sports, and $19 \%$ said they do no sports in their free time. In our sample, already $39 \%$ of the students had attended a dance project, and about two-thirds had participated in previous theatre projects. Furthermore, nearly $27 \%$ of the students reported that they played a musical instrument. Students' personality traits were assessed in the pre-test, using an age-sensitive reformulation of the Big-Five-Inventory-10 (Rammstedt, Kemper, Klein, Beierlein, \& Kovaleva, 2012). In a nutshell, students ranked themselves in the middle of the Likert spectrum, with only small standard deviations (details are provided in Table 1). Notable spikes were found in the dimensions "extraversion," "openness to experience," and "agreeableness." "Extraversion" ( $M=4.40)$ and "openness to experience" $(M=4.44)$ scored slightly higher than the other dimensions. Furthermore "extraversion" has a very small standard deviation $(S D=0.82)$. The lowest score yielded the dimension "agreeableness" $(M=3.86)$. All in all, from the data assessed we propose that the majority of the students could be described as having a multi-ethnical background and being culturally active, extraverted, and open to new experiences.

Table 1. Results for the Big-Five-Inventory ( $1=$ "not agree" to 7 = "agree")

\begin{tabular}{llll}
\hline Subject & Sample size & Mean $(\boldsymbol{M})$ & Standard deviation (SD) \\
\hline Extraversion & 25 & 4.40 & 0.82 \\
Neuroticism & 24 & 4.19 & 0.92 \\
Openness to experience & 24 & 4.44 & 1.05 \\
Conscientiousness & 24 & 4.21 & 1.05 \\
Agreeableness & 25 & 3.86 & 0.99 \\
\hline
\end{tabular}

To assess the students' interest in the project related STEM-subjects, appreciation of galvanization, physics and chemistry was measured with five items for each dimension (see Table 2). While all the parameters of Cronbach's a were above .8, the small sample size of $n=50$ must be considered. In the second part of the questionnaire, students' perspectives on different aspects of the project, such as artistic practices, self-perception, and classroom climate were assessed. 
Since the data is a paired sample with a very small sample size, dependent t-tests for paired samples were used in the analysis, calculating Wilcoxon signed-rank tests for cross-checking every dimension. Finally, Cohen's $d$ is provided to estimate the effect size (Bortz, 2005, p. 145).

Table 2. Quality of measurement for STEAM aspiration.

\begin{tabular}{llll}
\hline Dimension & $\mathbf{n}$ of Items & Cronbach's $\boldsymbol{\alpha}$ & Item example \\
\hline Galvanization & 4 & 0.89 & I want to know more about galvanization. \\
Physics & 5 & 0.82 & I am also interested in physics outside school. \\
Chemistry & 5 & 0.82 & Chemistry gives me fun. \\
\hline
\end{tabular}

\section{Results}

Analysis of the participants' interest in chemistry, physics, and galvanization shows an increase for all three dimensions. As Table 3 and Figure 2 show, significant changes in interest were measured for both the project topic (galvanization) and physics. The project had a remarkable effect on students' interest for the topic of galvanization, with an effect size of $d=1.15$. Here, the mean changed from 1.67 to 2.54. The effect on students' interest in physics was also strong, with $d=0.82$. The score increased by 0.41 scale points from measurement 1 to 2 . It is worth noting that also the standard deviation is very small. This suggests that the entire group clearly experienced a positive change of attitude with respect to physics. No significant effect was found for chemistry between time point 1 and time point 2 , but measurements for chemistry aspiration show very small standard deviations at both time points.

Table 3. Effects on aspiration of STEM-subjects ( $n=24$; scale: $1=$ "not agree" to $7=$ "agree")

\begin{tabular}{lcccccccc}
\hline \multirow{2}{*}{ Dimension } & $\mathrm{t}_{1}$ & $\mathrm{t}_{2}$ & \multicolumn{3}{c}{ paired $\boldsymbol{t}$-test } & \multicolumn{2}{c}{ Wilcoxon Test } & $\boldsymbol{d}$ \\
& $M(S D)$ & $M(S D)$ & $d f$ & $t$ & $p$ & $z$ & $p$ & \\
\hline Galvanisation & $1.67(1.00)$ & $2.54(1.22)$ & 23 & -4.00 & 0.001 & -3.68 & $<.001$ & 1.15 \\
Physics & $2.71(0.68)$ & $3.12(0.84)$ & 23 & -2.83 & 0.009 & -2.62 & 0.009 & 0.82 \\
Chemistry & $2.70(0.88)$ & $2.84(0.90)$ & 23 & -0.97 & 0.341 & -1.25 & 0.211 & 0.28 \\
\hline
\end{tabular}




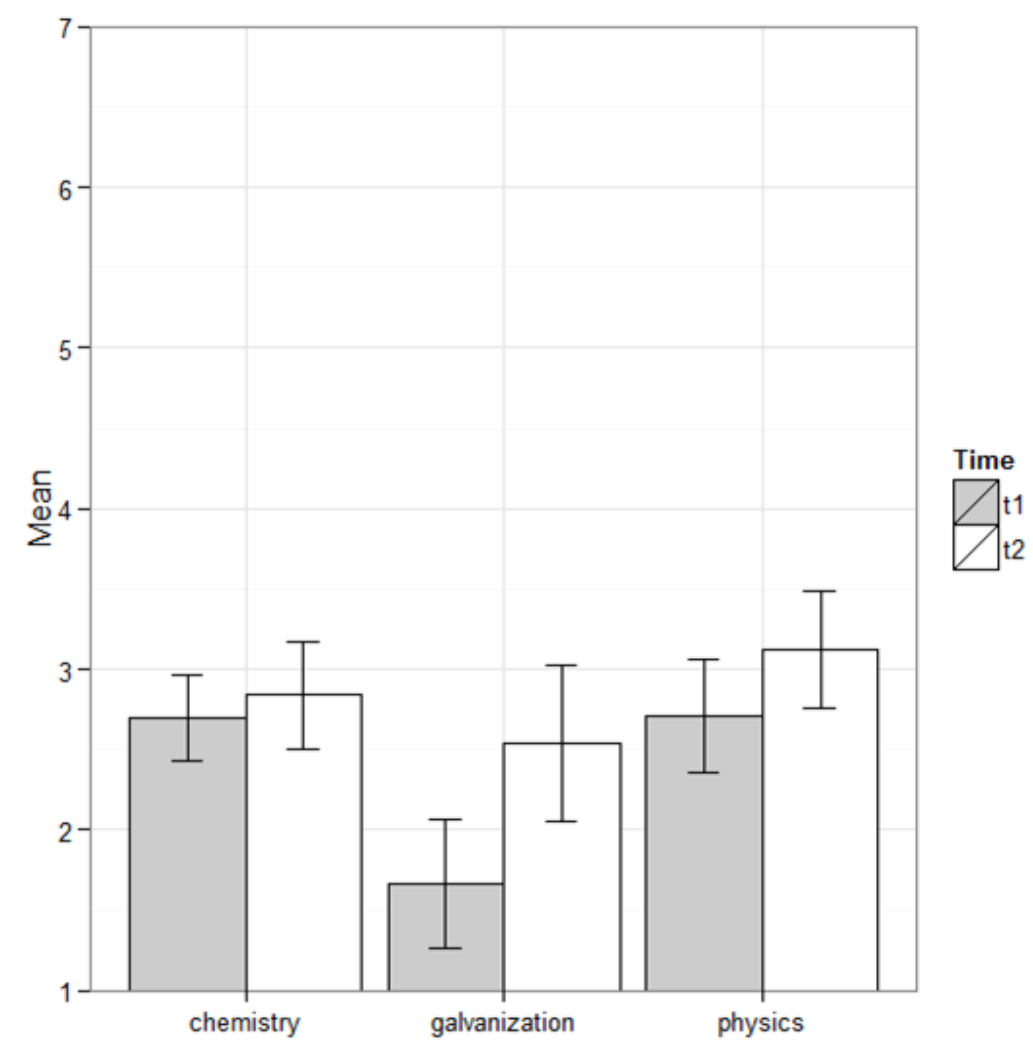

Figure 2. Change of appreciation for chemistry, galvanization and physics from time point 1 ( $\mathrm{t} 1$, beginning of Phase 3 ) to time point 2 ( $\mathrm{t} 2$, end of Phase 4). Scale: 1 = "not agree" to 7= "agree", Confidence level: $95 \%$.

Let us have a look at the questions that tell us more about how students see the project, as well as how they experience themselves in the project, their creativity, and the learning atmosphere. The greatest effect can be noted for the statement "I can orient myself successfully towards the tasks of the three artists" with $d=1.08$ and an increased mean ( $M 1=4.38$ to $M 2=5.46)$. We interpret this effect as indicating an increase in mastery experience or positive effects of verbal persuasion. It also suggests that the students gradually adapted to the artists' individual styles of teaching.

The statement "The whole class works well together during the project" was also ranked higher from time point 1 to time point to 2 , with an effect size of $d=1.04$. This result suggests that the pedagogical effect of art-based education was successful in creating an experience that fosters empathy and shared experience and social inclusion among the group of student participants. Although no significant effect was found for the item "I am more encouraged to try something new in the project than in school," the mean for empathy, shared experience and social inclusion increased from 4.33 to 5.08 scale points. 
Table 4. Questions to get an insight into students' appreciation of the artistic process, aesthetic perception and self-perception ( $n=24$; scale: 1 = "not agree" to 7 = "agree")

\begin{tabular}{|c|c|c|c|c|c|c|c|c|}
\hline \multirow{2}{*}{ Item } & \multirow{2}{*}{$\begin{array}{c}t_{1} \\
M(S D)\end{array}$} & \multirow{2}{*}{$\begin{array}{c}t_{2} \\
M(S D)\end{array}$} & \multicolumn{3}{|c|}{ paired t-test } & \multicolumn{2}{|c|}{ Wilcoxon Test } & \multirow{2}{*}{$d$} \\
\hline & & & $d f$ & $t$ & $p$ & $z$ & $p$ & \\
\hline I have a good feeling for rhythm. & $\begin{array}{c}4.21 \\
(1.45)\end{array}$ & $\begin{array}{c}4.50 \\
(1.25)\end{array}$ & 23 & -1.77 & 0.090 & -1.70 & 0.090 & 0.51 \\
\hline $\begin{array}{l}\text { I have great interest to participate } \\
\text { in an arts-project on galvanisation. }\end{array}$ & $\begin{array}{c}1.92 \\
(1.38)\end{array}$ & $\begin{array}{l}2.67 \\
(1.31)\end{array}$ & 23 & -2.07 & 0.050 & -2.53 & 0.012 & 0.60 \\
\hline $\begin{array}{l}\text { I have own artistic ideas I wish to } \\
\text { realise in the project. }\end{array}$ & $\begin{array}{c}2.92 \\
(1.53)\end{array}$ & $\begin{array}{c}3.29 \\
(1.27)\end{array}$ & 23 & -1.00 & 0.328 & -0.88 & 0.379 & 0.28 \\
\hline $\begin{array}{l}\text { The whole class works well } \\
\text { together during the project. }\end{array}$ & $\begin{array}{c}4.36 \\
(1.25)\end{array}$ & $\begin{array}{c}5.25 \\
(1.39)\end{array}$ & 23 & -3.19 & 0.004 & -2.81 & 0.005 & 1.04 \\
\hline Creative work gives me fun. & $\begin{array}{c}4.00 \\
(1.89)\end{array}$ & $\begin{array}{c}4.25 \\
(1.51)\end{array}$ & 23 & -0.58 & 0.567 & -0.57 & 0.567 & 0.17 \\
\hline $\begin{array}{l}\text { I enjoy participating in creative } \\
\text { projects in school. }\end{array}$ & $\begin{array}{l}4.08 \\
(1.72)\end{array}$ & $\begin{array}{c}4.63 \\
(1.21)\end{array}$ & 23 & -2.12 & 0.045 & -2.07 & 0.039 & 0.62 \\
\hline $\begin{array}{l}\text { I can orient myself successfully } \\
\text { towards the tasks of the three } \\
\text { artists. }\end{array}$ & $\begin{array}{l}4.38 \\
(1.50)\end{array}$ & $\begin{array}{l}5.46 \\
(1.25)\end{array}$ & 23 & -3.76 & 0.001 & -3.18 & 0.001 & 1.08 \\
\hline $\begin{array}{l}\text { I can express myself well using } \\
\text { artistic means. }\end{array}$ & $\begin{array}{c}3.38 \\
(1.53)\end{array}$ & $\begin{array}{c}4.13 \\
(1.04)\end{array}$ & 23 & -2.48 & 0.021 & -2.38 & 0.017 & 0.71 \\
\hline $\begin{array}{l}\text { I have a precise understanding of } \\
\text { what an arts performance is. }\end{array}$ & $\begin{array}{l}3.63 \\
(1.61)\end{array}$ & $\begin{array}{c}4.33 \\
(1.40)\end{array}$ & 23 & -2.10 & 0.047 & -2.17 & 0.030 & 0.60 \\
\hline $\begin{array}{l}\text { I am more encouraged to try } \\
\text { something new in the project than } \\
\text { in school. }\end{array}$ & $\begin{array}{c}4.33 \\
(1.61)\end{array}$ & $\begin{array}{c}5.08 \\
(1.18)\end{array}$ & 23 & -2.19 & 0.039 & -1.53 & 0.126 & 0.63 \\
\hline
\end{tabular}

Artistic and creative expression also yielded significant effects. In particular, the statement "I can express myself well using artistic means" scored significantly higher in the post-test with an effect of $d=0.71$. This experience was reflected in the relatively high scores for the statements "I have great interest to participate in an arts-project on galvanization" ( $d=0.6)$ and "I enjoy participating in creative projects in school" ( $d$ $=0.62$ ). The score for "I have a precise understanding of what an arts performance is" $(d=0.6)$ also changed, indicating an appreciable increase in the participants' level of cultural education and awareness. 


\section{Summary and Conclusions}

Adding to the growing body of research into STEAM and art-informed education in STEM, this report showed the positive impacts of a science theatre project on student interest in physics, chemistry, galvanization, and artistic practices.

The science theatre project "Not All That Glitters Is Gold" was a singular project with a lower-secondary school class, aiming to further education and to support the lived cultural diversity in a heterogeneous classroom. It also offered students an occupational orientation in the subject of galvanization. Engaged in art-based learning the participating students appeared to enjoy themselves with their classmates during the project; their interest in creative expression and hunger for knowledge in the related STEM topics increased. This impression was confirmed by the accompanying pen-and-paper survey, in which participating students reported having strong positive experiences. The data suggests that the students experienced themselves as proactive participants in the learning experience-that is, as more than mere receivers of content knowledge. The study results are in accord with those of previous studies outlined at the beginning of this article.

In retrospective, using the Lincoln Center framework (see section 3), for reflection, "Not All That Glitters Is Gold" provided learning within four of the nine core capacities, namely embodying, making connections, creating meaning, and taking action. The overall project and workshop design matched the Bernstein process (see section 3) of experience, inquiry, creativity, and reflection only to some extent. While artistic and subject-related experience was provided and creativity given its place to a large extend, inquiry and reflection remained less represented and accounted for in the project. There are most likely multiple reasons for this. In particular, this science theatre project took place within the confinements of an educational institution, thus having to act within the accepted boundaries of school education. Despite the wish to provide the students with a journey into transdisciplinary STEAM education, it soon became clear that, within the given conditions, the practical scheme had to be set up as an art-informed science theatre project. This way the project was adaptive to formal education to the extend as the existing values and norms of formal education were slightly questioned but not pushed forward or changed (Sterling, 2001; Schulze Heuling \& Fooladi, forthcoming). In other words, within this educational project an equality between students' scientific and artistic inquiry into galvanization and the science related to it was not attained. 
Additionally, a few methodological remarks should be made. First, the study is a case study with a small sample size and lacks a control group which both limit the empirical significance of the results. Second, a follow-up study would have provided information on the long-term nature of the measured effects. Third, it is noteworthy that specific student characteristics might have supported the positive study results: More than a third of the students had previously participated in a 'dance in school' project, nearly a third indicated to play a music instrument, which we interpret as having a background in cultural education, and finally the big-five analysis revealed that the class had the tendency to be extrovert and open to new experiences.

All in all, this study showed the positive impact of a science theatre project on students' interest in STEM. The significant increase of appreciation of the subject matter and artistic practices as well as improved classroom spirit show the strengths of simultaneously teaching art \& science. Even more: Considering the intercultural background of the students and that both, school and environment of the students are located in a disadvantaged area of Hamburg, the study results clearly make a case for art-informed STEM education as a socially inclusive practice and for successfully promoting interest in STEM and the arts among disadvantaged students.

\section{References}

Allchin, D. \& Zemplen, G. (2020). Finding the place of argumentation in science education:

Epistemics and Whole Science. Science Education (early view)

https://doi.org/10.1002/sce.21589.

Amabile, T.M. (1983). The social psychology of creativity. New York: Springer.

Annenberg Institute for School Reform at Brown University (2003). The Arts and School Reform:

Lessons and Possibilities From the Annenberg Challenge Arts Projects.

http://www.annenberginstitute.org/sites/default/files/

product/253/files/Arts_Challenge.pdf.

Bernstein New American Schools (2003). The Leonard Bernstein center for learning.

http://naschools.org/contentViewer.asp?highlightID=57\&catID=189 Abgerufen 15.05.2017.

Bortz, J. (2005). Statistik für Sozialwissenschaftler. Berlin, Springer.

Boy, G. A. (2013). From STEM to STEAM: Toward a Human-Centered Education. http://ntrs.nasa.gov/archive/nasa/casi.ntrs.nasa.gov/20130011666.pdf. Abgerufen $15 \cdot 05.2017$

Burg, J., \& Lüttringhaus, K. (2005). Entertaining with Science, Educating with Dance. http://citeseerx.ist.psu.edu/viewdoc/download?doi=10.1.1.75.9928\&rep=rep1\&type=pdf

Burton, J., Horowitz, R., \& Abeles, H. (1999). Learning in and through the arts: Curriculum implications. New York: Teachers College, Columbia University.

CERN (2020, July 5). Creativity across cultures. Retrieved from https://arts.cern 
Chemi, T. (2017). Science and the Arts: Curriculum Integration, Learning, and Emotions in Schools. In A. Bellocchi, C. Quingley, \& K. Otrel-Cass (Eds.), Exploring Emotions, Aesthetics and Wellbeing in Science Education Research (2017 ed., Vol. 13, pp. 203-218). Springer. Cultural Studies of Science Education Vol. 13 https://doi.org/10.1007/978-3-31943353-0_11

Efland, A.D. (2002). Art and cognition: Integrating the visual arts in the curriculum. NY: Teachers College Press.

Eisner, E. W. (2002). What Can Education Learn from the Arts About the Practice of Education?. Journal of curriculum and supervision, 18(1), 4-16.

Eschenberg, K. (2006). Scientist as artist: The role of Imagination. Physics Today, 7(59), 10.

Fiske, E. (1999). Champions of change: Impact of the arts on learning. http://www.artsedge.kennedy-center.org/champions/ pdfs/ChampsReport.pdf. Abgerufen 15.05.2017.

Fogg, T. L., \& Smith, M. (2002). The Artists-in-the-Classroom Project: A Closer Look. The Educational Forum, 66(1), 60-70. https://doi.org/10.1080/00131720108984800

Garvis, S., \& Pendergast, D. (2010). Supporting novice teachers of the arts. International Journal of Education \& the Arts, 11(8).

Gedžune, I. \& Gedžune, G. (2011). Exploring and Promoting Ecological Consciousness in Teacher Education: The Possibilities of Educational Action Research in Education for Sustainable Development. Journal of Teacher Education for Sustainability, 13(1), 43-61.

Gollin, G. (2016). Physics and Dance.

http://www.hep.uiuc.efnordu/home/ggollin/dance/dance_physics.html.

Greene, M. (2001). Variations on a blue guitar: The Lincoln Center Institute Lectures on Aesthetic. Teachers College Press, New York, NY.

Heering, P. \& Schulze Heuling, L. (2020). Physik auf der Bühne [Physics on Stage], special issue, Naturwissenschaften im Unterricht Physik, 176.

Holzer, M. F. (2005, May 5)). Teaching and learning at the Lincoln Center Institute. Retrieved from www.lcinstitute.org.

Irving, L. T. (2015). Teaching statistics using dance and movement. Frontiers in Psychology, $6(50)$.

Jackson, S. (2005). Performing Show and Tell: Disciplines of Visual Culture and Performance Studies. journal of visual culture, 4(2), 163-177.

Katz, P. (2016). Drawing for Science Education: An International Perspective. Sense Publishers.

Khine, M. S., \& Areepattamannil, S. (2019). STEAM Education: Theory and Practice. Cham: Springer International Publishing AG

Knowles, J. \& Cole, A. (2008). Handbook of the Arts in Qualitative Research: Perspectives, Methodologies, Examples, and Issues. SAGE Publications.

Kolstø, S.D. (2001). Scientific literacy for citizenship: Tools for dealing with the science dimension of controversial socioscientific issues. Science Education, 85(3), 291-310

Leavy, P. (2015). Method Meets Art, Second Edition: Art-Based Research Practice. Guilford Publications.

Macintyre Latta, M., Buck, G. \& Beckenhauer, A. (2007). Formative assessment requires artistic vision. International Journal of Education \& the Arts, 8(4).

Madirosian, G. H. \& Fox, L. (2003). Literacy learning intervention for at-risk students through arts-based instruction: A case study of the imagination quest model. Presentation at the Learning Conference 2003: What Learning Means. Institute of Education, University of London. 
Marshall, J. (2014) Transdisciplinarity and Art Integration: Toward a New Understanding of ArtBased Learning across the Curriculum, Studies in Art Education, 55(2), 104-127

Le Maréchal J.-F., Bertin E. \& Hallet-Eghayan M. (2009) Science et danse: les mouvements collectifs. Bulletin de l'Union des Physiciens, vol.103, n919, 1057-1068.

Miendlarzewska, E. \& Trost, W. (2013). How musical training affects cognitive development: rhythm, reward and other modulating variables. Frontiers in Neuroscience, 7(279).

Najami, N., Hugerat, M., Khalil, K. and Hofstein, A. (2019) Effectiveness of Teaching Science by Drama. Creative Education, 10(1), 97-110.

North Carolina A+ (2020, July 28). A+ schools of North Carolina. Retrieved from https://www.ncarts.org/aplus-schools

Oppenheimer, F. (1972). The Exploratorium: A Playful Museum Combines Perception and Art in Science Education. American Journal of Physics, 4O(7), 978-984.

Oreck, B. (2004). The Artistic and Professional Development of Teachers: A Study of Teachers' Attitudes toward and Use of the Arts in Teaching. Journal of Teacher Education, 55(55).

Orthofer, M. A. (2002). The scientist on the stage: A survey. Interdisciplinary Science Reviews, $27(3), 173-183$.

Perignat, E., \& Katz-Buonincontro, J. (2019). STEAM in practice and research: An integrative literature review. Thinking skills and creativity, 31, 31-43.

Rammstedt, B., Kemper, C., Klein, M., Beierlein, C. \& Kovaleva, A. (2012). Eine kurze Skala zur Messung der fünf Dimensionen der Persönlichkeit: Big-Five-Inventory-10 (BFI-10), GESIS Working Papers 2012|23. Cologn: GESIS.

Reif, N. \& Grant, L. (2010). Culturally responsive classrooms through art integration. Journal of Praxis in Multicultural Education, 5(1).

Reimer, B. (1970). A Philosophy of Music Education. Englewood Cliffs, NJ: Prentice-Hall.

Psilos, P. (2002). The impact of arts education on workforce preparation: Issue brief. Washington, DC: National Governors' Association, Center for Best Practices.

Schellenberg, E. (2003). Does exposure to music have beneficial side-effects? The cognitive neuroscience of music. Oxford University Press, Oxford.

Schultz K. K., Brackbill M. L. (2009). Instructional design and assessment: teaching electrocardiogram basics using dance and movement. Am. J. Pharm. Educ. 73(4), 1-5.

Schulze Heuling, L. (2017). Cultural Diversity in Science Education. Integrating Arts-based Approaches in Science Education to promote Plurality and Diversity. L. Schulze Heuling (Hg.), Embracing the Other. How the Inclusive Classroom Brings Fresh Ideas to Science and Education. Flensburg University Press.

Schulze Heuling, L \& Fooladi, E.C. (forthcoming). En dialog om estetikkens plass i utdanning for bærekraftig utvikling. Presthus Heggen, M. \& Mestad, I., Flerfaglige blikk på bærekraft $i$ barnehage, skole og lærerutdanninger, Cappelen Damm Akademisk Norway.

Snyder, S. (2015, June 3). Total literacy and the arts. Retrieved from www.aeideas.com/articles/tlandarts

Soep, E. (2005). Critique: Where Art Meets Assessment. Phi Delta Kappan, 87(1), 38-63. https://doi.org/10.1177/003172170508700109.

Stolberg, T. (2006). Communicating Science through the Language of Dance: A Journey of Education and Reflection. Leonardo 39(5), 426-432

Sterling, S. (2001). Sustainable education. Re-visioning learning and change, Cambridge: Green Books.

Stronge, J. H. (2002). Qualities of effective teachers. Association for Supervision and Curriculum Development, VA, Alexandria. 
Tracey, S. (2009). Crossing Thresholds and Expanding Conceptual Spaces: Using Arts-Based Methods to Extend Teachers' Perceptions of Literacy. Learning Landscapes, 3(1), 243-262. van Eijck, M. \& Roth,W.-M. (2011). Cultural diversity in science education through Novelization: Against the Epicization of science and cultural centralization. Journal of Research in Science Teaching, 48(7), 824-847.

Veen, J.v. d. (2012). Draw your physics homework? Art as a Path to Understanding in Physics Teaching. American Educational Research Journal, 49(2), 356-407.

Weisberg, R.W. (1999). Creativity and knowledge: A challenge to theories. In R.J. Sternberg (ed.), Handbook of creativity (pp. 226-250). New York: Cambridge University Press.

Weisskopf, V. F. (1976). Is physics human? Physics Education, 11(2), 75.

Williams, K. (2011): Teaching Techniques in the Science Laboratory. Core 1O(2). 